\title{
DIVERSITY OF MOLLUSC COMMUNITIES IN THE SEAGRASS BED IN PULAU GAZUMBO, PENANG, MALAYSIA
}

\author{
Aileen Tan Shau Hwai", Nur-najmi Basyeer Bt. Abdul Karim and Zulfigar Yasin \\ School of Biological Sciences \\ Universiti Sains Malaysia, 11800 Minden, Penang, Malaysia \\ e-mail: aileen@usm.my
}

\begin{abstract}
A study on the diversity of mollusc communities inhabiting the seagrass bed of Pulau Gazumbo, Penang, which is known as a manmade island covered with seagrass communities in Malaysia, was conducted. The seagrass species reported in this island are Halophila ovalis Hook (1858), H. ovata Gaud (1827), H. spinulosa Aschers (1875) and H. beccarii den Hartog (1977), with $H$. ovalis being the dominant species. A total of 15 random $1 \mathrm{~m} \times 1 \mathrm{~m}$ quadrates were taken on the seagrass bed around the island during lowest tide. A total of 14 species from 12 genera and 9 families of gastropods and a total of 8 species from 8 genera and 6 families of bivalves were reported in this study. Nassarius livescens from the Family Nassariidae is the most dominant molluscs (18 individuals per $\mathrm{m}^{2}$ ) inhabiting the seagrass beds.
\end{abstract}

Keywords: Diversity, Mollusc communities, Seagrass bed, Pulau Gazumbo, Penang Malaysia.

\section{INTRODUCTION}

In terms of biodiversity, Malaysia is considered as one of the countries located at the hotspot of the richest region in the Indo-Pacific (Briggs, 1974). Intertidal seagrass areas are rich in molluscs, but density and diversity are vulnerable to human exploitation since these benthic animals are immobile compared to fishes or other planktonic organism (Krebs, 1985).

Seagrass is an important habitat for zoobenthos in general, including many species of molluscs. Most of the seagrass areas in Malaysia are located on the east coast of Peninsular Malaysia and in East Malaysia, with only two seagrass areas being reported in the west coast of Peninsular Malaysia, namely in Pulau Langkawi and Pulau Gazumbo.

Marine biologists from Muka Head Marine Research Station, Universiti Sains Malaysia, have been working on the Pulau Gazumbo since 2003. The team has monitored the abundance and biomass of seagrasses and associated animal communities of the seagrass bed found here. The current assessment looked at the diversity of mollusc communities in the seagrass bed of Pulau Gazumbo.

\section{MATERIAL AND METHODS}

Pulau Gazumbo is a man-made islet as a result of dumped dredged materials from the South Channel when the Penang Bridge was constructed in October 1985. Pulau Gazumbo Besar (Fig. 1), the larger of the two man-made islets at the west end of Penang Bridge, has yet to be officially named by the State of Penang. 'Gazumbo' is a nickname originally chosen by students whom had carried out earlier research on the islet two decades ago. The size of the islet is approximately $0.02 \mathrm{~km}^{2}$.

A small mangrove stand is located at the western-southwestern section of this pea-shaped islet. Since mangroves are also nature's own sediment trap it is also within this area that most mudflats are found. On this section were also found abundant shell debris.

A $1 \mathrm{~m} \times 1 \mathrm{~m}$ quadrat was used to sample the seagrass population on the man-made island. Fifteen quadrates were laid around the seagrass bed around the island during low tide. All the molluscs specimens found within each quadrat were identified and counted. Voucher specimens were collected where necessary, where the specimens were placed in labelled plastic bags. 


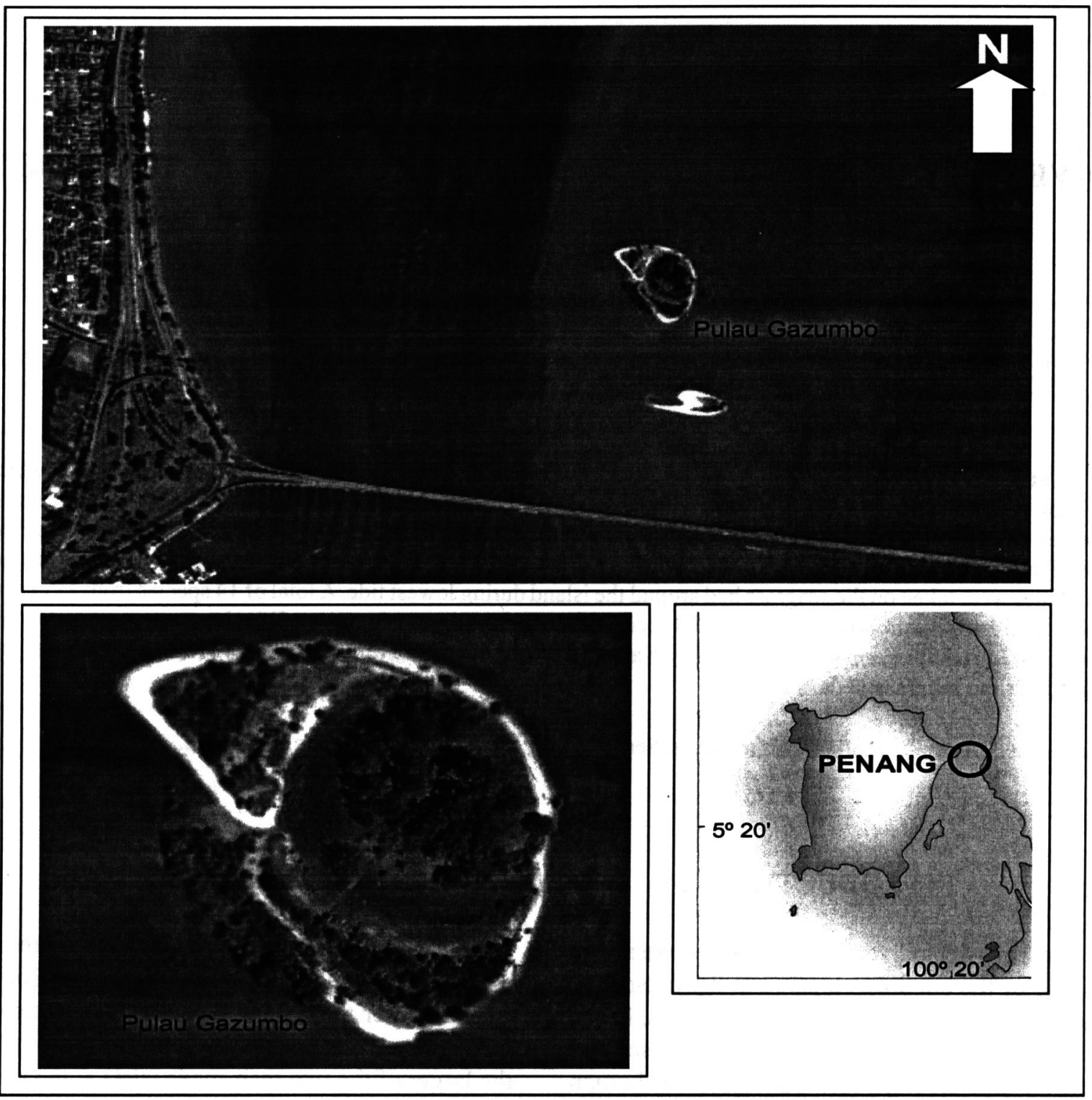

Figure 1. Location of the man-made Pulau Gazumbo, Penang.

Further identification was done in the laboratory using identification keys from Arnold and Birtles (1989), Abott $(1974,1991)$ and Nateewathana (1995). The behaviour of the molluscs during the sampling was noted.

\section{RESULTS}

Four species of seagrasses were identified on this islet. They are Halophila ovalis Hook (1858), Halophila ovata Gaud (1827), Halophila beccarii Aschers (1971) and Halophila spinulosa Aschers (1875). All four species were found in waters of less than $1 \mathrm{~m}$ depth. The dominant species was $H$. ovalis, which was found to exist as two-species association with $H$. ovata. Monospecific communities occur for $H$. beccarii and $H$. spinulosa. $H$. beccarii was found only within the soft muddy substratum of the small mangrove stand on the islet, whilst $H$. spinulosa was found only in one location on the man-made islet.

A total of 22 species of 20 genera and 15 families of molluscs were found in the seagrass bed of Pulau Gazumbo, Penang. Gastropods dominated the survey area with 14 species, while 8 species of Pelecypods were reported. Table 1 shows the species composition of molluscs in the seagrass bed of Pulau Gazumbo. More than $74 \%$ of all the molluscs recorded were gastropods, and 
Table 1. Species composition of molluscs in seagrass bed of Pulau Gazumbo, Penang, Malaysia.

\begin{tabular}{|c|c|c|c|}
\hline Class & Family & Species & $\begin{array}{l}\text { No. of individuals recorded } \\
\left(\# \text { per } \mathrm{m}^{2}\right)\end{array}$ \\
\hline \multirow{14}{*}{ Gastropoda } & Nassarridae & Nassarius livescens & 18 \\
\hline & & Nassarius stolatus & 15 \\
\hline & Potamididae & Cerithidea cingulata & 17 \\
\hline & Marginellidae & Marginella ventricosa & 4 \\
\hline & Melongenidae & Pugilina cochlidium & 3 \\
\hline & Muricidae & Drupa sp. & 2 \\
\hline & & Murex trapa & 3 \\
\hline & & Thais lacera & 3 \\
\hline & & Thais sp. & 1 \\
\hline & Naticidae & Polinices tumidus & 8 \\
\hline & & Natica tigrina & 1 \\
\hline & Trochidae & Monilea sp. & 1 \\
\hline & Turridae & Clathrodillia jeffreysii & 2 \\
\hline & Turritellidae & Turritella terebra & 2 \\
\hline \multicolumn{3}{|c|}{ Subtotal } & 80 \\
\hline \multirow{8}{*}{ Bivalvia } & Arcidae & Anadara antiquata & 2 \\
\hline & Mytilidae & Modiolus nitidus & 1 \\
\hline & Pectinidae & Chlamys sp. & 1 \\
\hline & & Pecten vexilum & 2 \\
\hline & Pinnidae & Pinna pectinata & 8 \\
\hline & Solenidae & Solen strictus & 1 \\
\hline & Veneridae & Paphia crassisulca & 2 \\
\hline & & Meretrix sp. & 10 \\
\hline \multicolumn{3}{|c|}{ Subtotal } & 27 \\
\hline \multicolumn{3}{|c|}{ Total } & 107 \\
\hline
\end{tabular}

the Family Nassarridae dominated the assemblage with respect to abundance. Among the gastropods, Nassarius predominated numerically; two of its species, $N$. livescens and $N$. stolatus, comprised nearly $31 \%(33 / 107)$ of all molluscs in the quantitative sample. The family Muricidae was by far the most diverse with 4 species, two of them in the genus Thais. Bivalves, represented by only 8 species, comprised $25 \%$ of the sample, with Meretrix sp., being the most dominant species among all the bivalves.
The density of living molluscs in the seagrass bed in Pulau Gazumbo was 107 individuals per $\mathrm{m}^{2}$. Nassarius livescens was the most abundant species in the seagrass bed ( 18 individual per $\mathrm{m}^{2}$ ), followed by Cerithidea cingulata (17 individual per $\mathrm{m}^{2}$ ) and Nassarius stolatus (15 individual per $\mathrm{m}^{2}$ ). All other gastropod species averaged less than 3 individual per $\mathrm{m}^{2}$, while the bivalves at average of 3.3 individual per $\mathrm{m}^{2}$.

Most of the molluscs especially the gastropods were found to be crawling freely $(36 \%)$ on the 
seagrass bed searching for food. Among the species that were crawling freely were Nassarius livescens, N. stolatus, Polinices tumidus and Natica tigrina. Some of the molluscs were reported to be attached to substrate (34\%) such as rocks or the seagrass leaves, which served as their food. A total of $30 \%$ of the molluscs were attached to other organisms such as other molluscs or crustaceans. Figure 2 shows the percentage of the molluscs behavior found in the seagrass bed in Pulau Gazumbo.

Most of the molluscs found in the seagrass bed were able to tolerate dryness up to one hour during the low tide. When exposed, the molluscs especially the gastropods were seen to be crawling towards areas which were still submerged with water, while the bivalves were seen hiding or drilling into the substrates for protection against dryness. Due to the intolerance towards dryness for a long period of time, most of the molluscs were found in depth of $0.2 \mathrm{~m}$.

\section{DISCUSSION}

The benthic fauna assemblage of molluscs occupying extensive seagrass beds may be very rich with respect to both diversity and abundance. The 15 transects sampled in this study on a seagrass bed in Pulau Gazumbo, Penang, Malaysia, harboured 22 species representing two molluscan classes, and a density of 107 individuals per $\mathrm{m}^{2}$.

The two species from the genus Nassarius and Cerithidea cingulata were the two dominant molluscs found in the seagrass bed in Pulau Gazumbo. Nassarius spp. were also reported to be widely spread and dominant in Surin National Park and Tarutao National Park in Thailand (Bussarawit, 1995), where the parks are located in the Andaman Sea. Cerithidea cingulata being the second dominant species in Pulau Gazumbo was due to its ability to tolerate dryness during the low tide. This species was reported in the upper zone where the area was exposed the longest during the low tide. Most of the other molluscs were not found in the upper zone which was dryer except for Cerithidea cingulata and Meretrix sp.

At the present time, very limited knowledge exists of the specific trophic roles of most species. The extent to which the predators depend on molluscs lower in the food chain and the other invertebrates present remain unknown. However, the two dominant species of Nassarius spp. belong to a family-group known for omnivory and including carnivores, herbivores, detritivores and scavengers (Britton and Morton, 1993, 1994). Meanwhile, Dharma (1988) has reported that Cerithidea cingulata is a herbivore. Based on the abundance of these three species of molluscs,

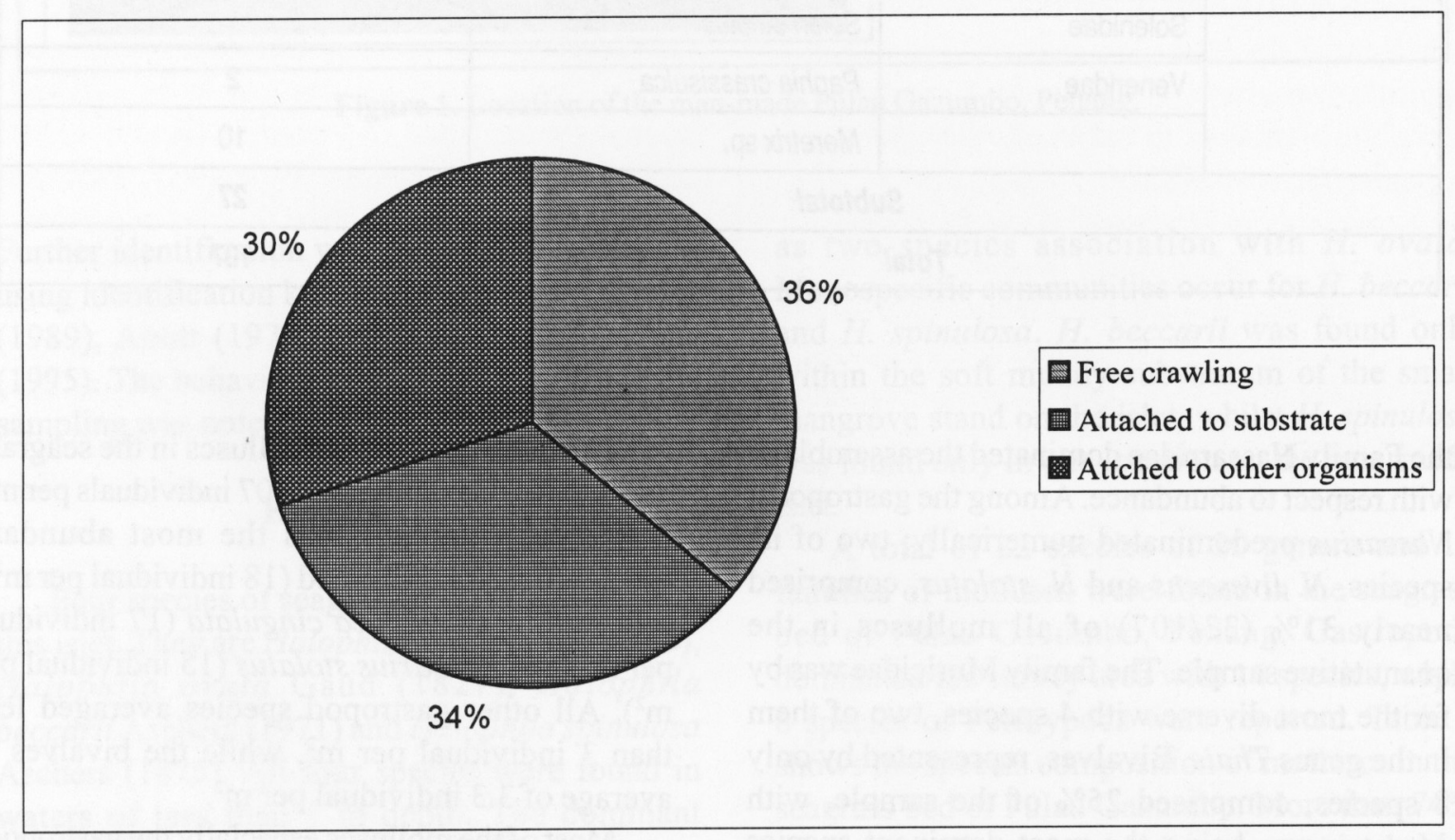

Figure 2. The percentage of the mollusks behavior found in the seagrass in Pulau Gazumbo. 
obviously the seagrass bed in Pulau Gazumbo served as a feeding ground for them.

Besides being a feeding ground for molluscs, the seagrass bed also served as a hiding site for the benthic organism. According to Edgar and Robertson (1992), seagrass bed acts as a hiding place for molluscs to avoid from predators during the day, where the molluscs are able to hide beneath the seagrass leaves.

Polinices tumidus and Murex trapa were found in Pulau Gazumbo and both these species are predators and carnivores. They feed on other molluscs and benthic organisms to survive. Similar findings have been reported by Kikuchi and Peres (1977) in the tropical seagrass beds in Madagascar.

This study has reported that most of the molluscs seemed to be crawling freely (36\%) during low tide. The remaining molluscs were found to be attached on either substrate or other organisms. The molluscs that were attached to the seagrass were herbivores such as Cerithidea cingulata and Marginella ventricosa. Most of the free crawling molluscs were seen to be moving among the seagrass rizomes, namely Nassarius livescens, N. stolatus, Polinices tumidus and Natica tigrina.

We have not been able to demonstrate the low species diversity in the study area, which could be related to the destruction of nature and Pulau Gazumbo being located at the middle of a small channel which experiencing heavy load of sedimentation. We have to conclude that a better understanding of the relationship between habitat type and molluscs species is required.

Acknowledgements. We thank the Universiti Sains Malaysia's Reef Research Group for their kind assistance and support in the field studies. We would like to thank JSPS-NaGISA Programme for their support to this paper to be presented at this International Seminar on Coastal Marine Science LIPI-JSPS.

\section{REFERENCES}

Abbott, R. T. 1974. American Seashells: The Marine Mollusca of the Atlantic and Pacific Coasts of North America. $2^{\text {nd }}$ Edition, Van Nostrand Reinhold Company, New York. 663 pp.

Abbott, R.T. 1991. Seashells of South East Asia. Graham Brash, Singapore. 145 pp.

Arnold, P.W. and R.A. Britles. 1989. Soft-sediment marine invertebrates of Southeast Asia and Australia: A Guide to Identification. Australian Institute of Marine Science. $271 \mathrm{pp}$.

Briggs, J.C. 1974. Marine zoogeography. McGraw-Hill, New York, London, 475 pp.

Britton, J.C. and B. Morton. 1993. Marine invertebrate scavengers. In: Morton, B. (ed.). Marine Biology of the South China Sea, Vol. 2. Pages 357-391. Hong Kong University Press, Hong Kong.

Britton, J.C. and B. Morton. 1994. Food choice, detection, time spent feeding and consumption by two species of subtidal Nassariidae from Monterey Bay, California. Veliger 37 (1): 81-92.

Bussarawit, S. 1995. Molluscs from the Marine National Parks: Surin and Le-pae Islands, Andaman Sea, Thailand. Proceedings of the Fifth Workshop of the Tropical Marine Molluscs Programme. Phuket Marine Biological Center Special Publication 15: 119-125.

Dharma, B. 1988. Siput dan Kerang Indonesia I (Indonesian Shells). PT. Sarana Graha, Jakarta. $111 \mathrm{pp}$.

Edgar, G.J. and A.I. Robertson. 1992. The Influence of seagrass structurte on the distribution and abundance of mobile epifauna: Pattern and process in a Western Australian Amphibolis Bed. Journal of Experimental Marine Biological Ecology 160: 13-31.

Krebs, C.J. 1985. Ecology. The experimental analysis of distribution and abundance. Harper \& Row Publ., New York, 800 pp.

Kikuchi, T. and J.M. Peres. 1977. Consumer ecology of seagrass beds: In: McRoy, C. P. \& Helfferich, C. (eds) Seagrass Ecosystems: A Scientific Perspective. Marcel Dekker, Inc., New York. 147193.

Nateewathana, A. 1995. Taxonomic account of commercial and edible molluscs, excluding Cephalopods of Thailand. Proceedings of the Fifth Workshop of the Tropical Marine Molluscs Programme. Phuket Marine Biological Center Special Publication 15: 93-116. 